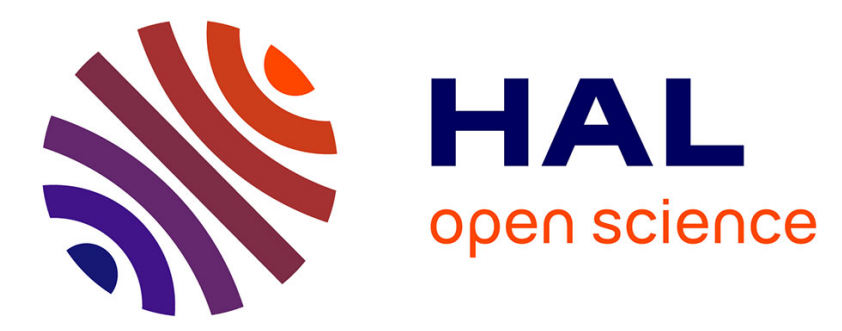

\title{
Plant diversity on skid trails in oak high forests: a matter of disturbance, micro-environmental conditions or forest age?
}

Liping Wei, A. Villemey, F. Hulin, Isabelle Bilger, Yann Dumas, Richard Chevalier, Frédéric Archaux, Frédéric Gosselin

\section{To cite this version:}

Liping Wei, A. Villemey, F. Hulin, Isabelle Bilger, Yann Dumas, et al.. Plant diversity on skid trails in oak high forests: a matter of disturbance, micro-environmental conditions or forest age?. Forest Ecology and Management, 2015, 338, pp.20-31. 10.1016/j.foreco.2014.11.018 . hal-01152839

\section{HAL Id: hal-01152839 \\ https://hal.science/hal-01152839}

Submitted on 18 May 2015

HAL is a multi-disciplinary open access archive for the deposit and dissemination of scientific research documents, whether they are published or not. The documents may come from teaching and research institutions in France or abroad, or from public or private research centers.
L'archive ouverte pluridisciplinaire HAL, est destinée au dépôt et à la diffusion de documents scientifiques de niveau recherche, publiés ou non, émanant des établissements d'enseignement et de recherche français ou étrangers, des laboratoires publics ou privés. 
1 Plant diversity on skid trails in oak high forests: a matter of disturbance,

2 micro-environmental conditions or forest age?

3

4

5 Liping Wei ${ }^{\mathrm{a}, \mathrm{b},{ }^{*}}$, Anne Villemey ${ }^{\mathrm{a}}$, Florian Hulin ${ }^{\mathrm{a}}$, Isabelle Bilger ${ }^{\mathrm{a}}$, Dumas Yann ${ }^{\mathrm{a}}$,

6 Richard Chevalier ${ }^{\mathrm{a}}$, Frédéric Archaux ${ }^{\mathrm{a}}$, Frédéric Gosselin ${ }^{\mathrm{a}}$

7

8

9

10

11

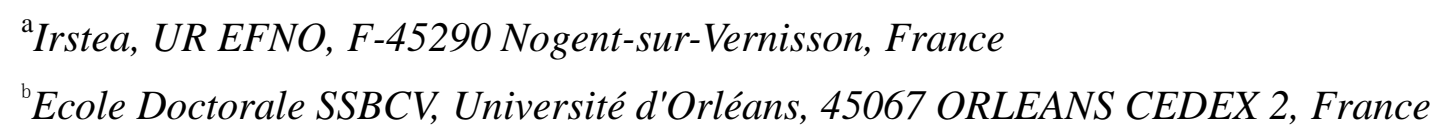

\section{Published in Forest Ecology and Management} (vol. 338, pages 20-31, doi: 10.1016/j.foreco.2014.11.018)

\section{Available at: http://www.sciencedirect.com/science/article/pii/S 0378112714006847} 25 6 27 8 


\section{Abstract}

Increasingly mechanized timber harvesting and the repeated use of skid trail networks may affect ground vegetation differently at subsequent stages in the forest rotation. At a fine scale, no studies have yet compared the influence of micro-environmental factors and the effects of skid trail disturbance on ground flora diversity. We investigated understory diversity patterns on skid trails in 30-, 50- and 63-year- old oak forests in the northern half of France. Subplots were placed on skid trail center, wheel track, skid trail edge plus an off-trail control. At each subplot, we measured soil moisture, soil compaction (penetration resistance and bulk density) and photosynthetic active radiation and recorded the abundance of all vascular plants. The richness and abundance of ground flora were calculated based on the classification of their life form, seed bank persistence, light preference and moisture requirements. For each ecological group, we found out its best diversity indicator from subplot location, micro-environmental factors (soil moisture and compaction, light) and stand attributes (stand type, basal area), then assessed the magnitude and negligibility of the effect of the best indicator. 1) Higher soil compaction compared to controls was detected on the tracks of skid trails in the 50- and 63-year- old stands. Neither soil moisture nor light varied with subplot location whatever the stand type. 2) The best diversity indicator that showed non-negligible effects included subplot location, and soil moisture or soil compaction. Compared to controls, skid trails in the 50- and 63-year-old stands were richer in tree and short-term seed bank species, while skid trails in the 30-year-old plots had no effect on ground flora. The abundance of tree and shade-tolerant species was also higher on skid trails. Soil moisture was positively correlated with the richness of low- and high- humidity species, shade-tolerant species and transient seed bank species as well as with the abundance of short-term seed bank species. Bulk density positively affected heliophilous species richness, while penetration resistance was positively related to shrub abundance. Skid trails and soil compaction in our research area had either no impact or a positive impact on ground flora diversity. Longer-term studies of skid trail effects are needed to validate these main findings.

Keywords: Ecological group; Soil compaction; Soil moisture; Model comparison; Fine scale; Mechanized harvesting 


\section{Introduction}

Successful forest management requires a thorough understanding of how forest ecosystems respond to disturbances. Disturbances, such as tree harvesting, are a primary factor influencing diversity and floristic composition in the forest (Roberts and Gilliam, 1995 and Berger et al., 2004). During the last several decades, manual felling and logging for forest management have evolved towards mechanized harvesting. Mechanized logging and timber harvesting rely on permanent evenly-distributed skid trail systems (Jarret, 2004), which have the advantage of confining disturbances to relatively smaller areas (Akbarimehr and Jalilvand, 2013) while providing easy access to the forest interior (Avon et al., 2013). The micro-site environment on skid trails is likely to differ from that of the forest interior due to canopy opening, higher soil compaction, soil nutrient loss or increased soil moisture on skid trails compared to undisturbed habitat (Buckley et al., 2003, Zenner and Berger, 2008 and Hattori et al., 2013). These environmental changes might explain the differences in ground flora that is observed between locations on and off skid trails (Swaine and Agyeman, 2008, Wolf, 2008 and Avon et al., 2013). Canopy cover is one of the most important factors that control a site's microclimate (Metzger and Schultz, 1984). Opening the canopy along skid trails can influence plant growth and competition patterns, especially between shade-tolerant and -intolerant species (Horn, 1971 and Planchais and Sinoquet, 1998). However, light level may not always remain high on skid trails years after logging or cutting operations. The time necessary for canopy closure together with the properties of the residual tree stands (age, height...) can greatly influence light availability on skid trails.

Soil compaction, a reduction in the volume of a given mass of soil (Gliński and Lipiec, 1990), is one of the major consequences of mechanized harvesting on skid trails (Ampoorter et al., 2010, Naghdi et al., 2010 and Solgi and Najafi, 2014). Therefore, it is often used as an indicator of forest floor disturbance resulting from machine use on skid trails. Very few studies to date have directly related ground flora to soil compaction measured on skid trails. For instance, Buckley et al. (2003) measured soil compaction in their description of the growth conditions on skid trails, but did not directly link it to ground flora diversity in the statistical analyses. We found only two studies investigating the relationship between soil compaction on skid 
trails and ground flora, however, their results were not consistent. Roovers et al. (2004) demonstrated that the intensity of soil compaction was highly (negatively) correlated with species cover and composition. On the contrary, Heninger et al. (2002) found that reduced Douglas-fir tree seedling growth on skid trails was unrelated to percentage increases in soil bulk density. Therefore, the role of compaction on skid trails in ground flora diversity needed to be validated.

Soil moisture is an important fine-scale factor affecting plants that has been described in many studies (Beckage et al., 2000 and Gray et al., 2012), but those dealing with skid trails did not find consistent results. For example, some studies demonstrated that soil moisture was higher on skid trails due to the removal of the canopy cover which reduced rainfall intercept and increased water intercept in the soil, while others found decreased water holding ability in wheel ruts after the first machine passes (Miller and Sirois, 1986, Buckley, et al., 2003, Ezzati et al., 2012 and Solgi and Najafi, 2014). Since the influence of canopy cover and machine use on soil moisture had not yet been jointly compared, we still need to study the soil moisture level on skid trials and its relation to canopy cover and soil disturbance.

Ground flora has the highest species diversity of all forest layers in temperate forests (Thomas et al., 1999). Because the diversity of ground flora is sensitive to a variety of factors such as overstory characteristics (Augusto et al., 2003, Nagaike et al., 2005 and Barbier et al., 2008), soil properties (Brunet et al., 1996), and forest disturbances and management practices (Hammond and Miller, 1998 and Wender et al., 1999), it is an important indicator of forest site quality and of the environmental impact of management (Pregitzer and Barnes, 1982 and Gilliam, 2002). The presence of skid trails, associated with frequent machine entry and accompanying disturbances, favors the introduction of ruderal, non-forest, exotic or heliophilous species (Buckley et al., 2003; Zenner and Berger, 2008; Avon et al., 2013). Identifying species that successfully establish and grow on skid trails, or inversely, that decrease or disappear on skid trails, is an important step for forest managers (Buckley et al, 2003). Furthermore, for those species that are favored by skid trails, it is important to distinguish whether these species are native or non-native species, and whether they are exclusive species. An increase in non-native species may threaten the existence or growth of native species on skid trails, especially when non-native species disperse into the forest interior.

The relative importance of different environmental or historical filters (e.g. 
disturbance) for ground flora diversity may vary with forest stage or stand development (Burton et al., 2011). Stands of different ages and types within a forest frequently experience different management regimes, i.e. they are subjected to varying intensities of machinery use and different distribution patterns of skid trails (Zenner, 2007 and Zenner and Berger, 2008). In addition, more mature forests managed with large machines need wider skid trails for wood extraction, potentially leading to the creation of deeper continuous ruts (Schack-Kirchner et al., 2007 and Picchio, 2012). Furthermore, trees at different ages may intercept different levels of light and water. Some studies have investigated the effect of skid trails on tree regeneration in different forest types (Liechty et al., 2002; Beaudet et al., 2014) but only limited research has compared the plant diversity patterns on skid trails in different forest types. Roovers et al. (2004) examined the effects of trampling on vegetation along skid trails in four vegetation types: two deciduous forest types, one grassland and one heathland, and showed that the increase in floristic dissimilarity from trail to undisturbed vegetation was higher in forests than in the grassland and the heathland, whereas no difference was detected between the two forest types.

Fine-scale studies of plant diversity patterns can provide insights into how historical and environmental filters interact across scales to influence vegetation locally (Leibold et al., 2004 and Burton et al., 2011). No previous studies have ever compared the influence of micro-environmental factors with skid trail disturbance to detect their effects on ground flora diversity. In our study, we investigated fine-scale understory diversity patterns in three forest types of varying tree maturity containing skid trail systems. We aimed to find the dominant factors affecting ground flora diversity among subplot location, soil moisture, soil compaction, light, stand type and basal area. We used subplots on and off skid trails to indirectly represent habitat exposed to frequent and infrequent disturbances. In addition, within the skid trails, we used three different locations - the middle of the trail, the wheel track and the trail edge - to represent the within-trail disturbance gradient. Relationships between ecological or functional groupings of plant species and environmental gradients can provide evidence for environmental filtering, particularly when the traits suggest an advantage in the associated environment (McGill et al., 2006 and Burton et al., 2011). The classification of ecological groups was based on the following four species traits (Table 1): life form, seed bank strategy, light and moisture requirements (data sources: Hodgson et al., 1995 and Julve, 2007). Our research questions were as 
163

follows: 1) What is the relative importance of subplot location, soil moisture, soil compaction and light on ground flora diversity? 2) Does this importance vary with stand type? 3) Are the dominant factors different among ground flora ecological groups?

\section{Material and methods}

\subsection{Study area}

The Montargis forest (4,090 ha, $48^{\circ} 01^{\prime} \mathrm{N}, 2^{\circ} 48^{\prime} \mathrm{E}$, Loiret, northern half of France) is an ancient state forest managed by the French National Forestry Office (ONF) around $110 \mathrm{~km}$ south of Paris. Elevation ranges from 95 to $132 \mathrm{~m}$ a.s.l. Climate is oceanic with a respective mean annual rainfall and temperature of about $647 \mathrm{~mm}$ and 10.9 C (Chevalier, 2003). Soil conditions are homogeneous, with plateau soils on a chalk substrate. There are small variations in soil texture (sandy to silt-sandy) and stone content (Chevalier, 2003). The dominant tree species are sessile oak (Quercus petraea), hornbeam (Carpinus betulus) and beech (Fagus sylvatica). The main management goal is to produce quality timber. Therefore, $70 \%$ of the area is managed as an oak even-aged high forest, where trees originate from seeds (Helms, 1998). Former standard-with-coppice (SWC) forest management with sessile oak as standards and hornbeam as coppice has been progressively replaced since 1857 by an even-aged high forest system dominated by oak. A high forest rotation is typically 180 to 200 years until trees reach $80 \mathrm{~cm}$ in diameter (ONF, 1996 and Jarret, 2004). All the even-aged high forest stands have experienced a seed-tree natural regeneration.

\subsection{Data collection}

We set up $20 \mathrm{~m}$ x $20 \mathrm{~m}$ quadrats in 36 even-aged high stands representing three stand types of different average ages (30, 50 and 63 years old - respectively STP30, STP50 and STP63, with 12 quadrats per stand type). The soil profile was tested by one of our authors (Richard Chevalier) in 2000. Site type was controlled to avoid site bias among forest types: variations among the variables related to site type were not significantly strong. We set up a 22-m-radius circular plot around the center of each 
quadrat and measured the diameter at $1.3 \mathrm{~m}$ height ("DBH", in $\mathrm{cm}$ ) for each tree, following Chevalier (2003). DBH was measured to calculate total tree basal area (all tree species combined, with oak contributing to $82 \%$ of the plot basal area on average). We then selected the skid trail that covered the largest area within the selected quadrat (Fig. 1 (a)). We inventoried vegetation and measured penetration resistance (PR), bulk density (BD) and light on four $0.5 \mathrm{~m} \times 5 \mathrm{~m}$ subplots systematically set out in each $20 \mathrm{~m} \times 20 \mathrm{~m}$ quadrat (Fig. 1 (a)): (1) on the wheel track of the skid trail (TR); (2) between the two wheel tracks of the skid trail (BE); (3) on the edge of the skid trail (BO); (4) halfway between two skid trails as a control (CO). The four subplots were oriented in the same direction as the skid trail and their centers were aligned orthogonally to the skid trail.

Skid trails are created by mowing vegetation during stand regeneration to provide easy access from roads to stand interiors. They are evenly distributed across the stands; this is especially true in lowland managed forests where management is likely to be intense, as is typical in Europe (Avon et al., 2013). The Montargis forest contains two types of parallel skid trails: primary (in STP30) and secondary skid trails (in STP50 and STP63). The primary skid trails are spaced $9 \mathrm{~m}$ apart and are $1.85 \mathrm{~m}$ wide on average (Fig. A1 in Appendix). The primary skid trails are mainly used by small cutting machines entering STP30 to remove shrubs, and wheel ruts are rarely found on most of these trails. The average spacing for secondary skid trails is $22 \mathrm{~m}$. The mean widths of these secondary skid trails are $2.23 \mathrm{~m}$ and $2.59 \mathrm{~m}$ in STP50 and STP63 respectively (Fig. A1 in Appendix). Wheel rut depths were $5.38 \mathrm{~cm}$ and 7.25 $\mathrm{cm}$ in STP50 and STP63 respectively. The secondary skid trails are mainly used by larger and heavier harvesters and skidders to cut and extract wood from the forest interior. During the maturing process of the stands, two thirds of the primary skid trails will be kept and used as secondary skid trails until the end of the rotation (150-180 years). The remaining primary skid trails are abandoned and gradually become an integral part of the stands.

Vegetation in each subplot was sampled once from May to end of July, 2012. Despite the seasonality of our sampling campaign, we were still able to detect vernal species, although probably in reduced abundance. Furthermore, only two vernal species: Anemone nemorosa and Hyacinthoides non-scripta are present on the mildly acidic soils of the Montargis forest.) Vascular plants below $2 \mathrm{~m}$ in height were recorded in each subplot following the Braun-Blanquet abundance-dominance 
classification with seven coefficients: $\mathrm{i},+, 1,2,3,4$ and 5 (i, one unique individual, cover $<5 \%$; +: very few individuals, total cover $<5 \%$; 1 , few to many individuals, total cover $<5 \% ; 2$, many individuals, total cover 5 to $25 \% ; 3$, total cover 25 to 50 $\%$; 4 , total cover 50 to $75 \% ; 5$, total cover $>75 \%$ ). When species abundance was being calculated, the coefficients were transformed into percentage cover classes as follows: $\mathrm{i}$ to $0.1 \%$; + to $0.5 \% ; 1$ to $5 \% ; 2$ to $17.5 \% ; 3$ to $37.5 \% ; 4$ to $62.5 \% ; 5$ to $87.5 \%$.

Soil compaction degree was assessed in each subplot from both PR and BD. The measurements were taken at the same time in November, 2012, when soil water content was near field capacity in the Montargis forest; penetrometer readings were thus less likely to be influenced by differences in soil moisture (Miller et al., 2001 and Godefroid and Koedam, 2004a). We took nine PR measurements per subplot. The locations of the PR points were fixed and numbered (1-9) as shown in Fig. 1 (b). Moisture at soil surface was measured simultaneously at the same nine points with a field tetra probe. We recorded PR $(\mathrm{MPa})$ at $1 \mathrm{~cm}$ depth intervals while continuously inserting $(2 \mathrm{~cm} / \mathrm{s}$ speed) a penetrologger (Eijkelkamp Agrisearch Equipment, the Netherlands) bipartite probing rod (with a cone-shaped tip of 60 degrees and $1 \mathrm{~cm}^{2}$ basal area surface) into the soil until it stopped due to high soil compaction or encountering a root or stone. The maximum measuring depth of a penetrologger is 80 $\mathrm{cm}$. In case the probing rod stopped less than $20 \mathrm{~cm}$ below ground, we took additional measurements (up to four) in a pre-determined direction and distance $(10 \mathrm{~cm})$ from the original point until the probe reached at least $20 \mathrm{~cm}$ in depth (Fig. 1 (b)). We also recorded the number of times we renewed the measurement (Nsam). We retained PR values from $0-20 \mathrm{~cm}$ in depth since, in previous studies, the strongest soil impact on ground vegetation appeared in this upper layer (Greacen and Sands, 1980 and Ampoorter et al., 2007). Furthermore, this layer is also generally free of the natural compaction that occurs in deeper soil layers (Godefroid and Koedam, 2004a). For the samples that had renewed measurements, we kept the PR and the maximum depth value from renewed measurement only (i.e. the one that had a depth of at least $20 \mathrm{~cm}$ ). The mean PR of the nine sampling spots at $0-20 \mathrm{~cm}$ in depth was used as a proxy for soil compaction level for each subplot.

We took one bulk density sampling in the center of each subplot (at the same point as PR No.5) at a depth of $10 \mathrm{~cm}$ with metallic cylinders $5 \mathrm{~cm}$ in diameter and $5 \mathrm{~cm}$ in height. To calculate BD and water content (Krzic et al., 2003), we weighed the fresh 
mass of each sample in the lab on the same day the sample was collected. We then dried the sample for 48 hours in an oven $\left(105^{\circ} \mathrm{C}\right)$ and recorded the dry mass.

We used four indicators for the degree of soil compaction since we felt that no single one was unambiguously more appropriate than the others: mean PR of the nine sampling spots at $0-20 \mathrm{~cm}$ in depth, mean number of measurements (Nsam) at each PR point, mean maximum depth of the nine sampling spots (MaxD), and mean BD. Nsam may be a useful predictor of the degree of compaction (the higher the Nsam, the more compacted the soil), although its relevance has not yet been tested. The MaxD decreases with increasing soil compaction and could reflect soil conditions related to plant root penetration. BD is more related to natural soil characteristics such as texture, organic matter content, soil structure (Cassel, 1982) and gravel content (Franzen et al., 1994), while PR mimics a root growing through soil. Relationships between PR and BD are not always consistent and were found to be non-linear in some studies (Smith et al., 1997, Vaz et al., 2001, Whalley et al., 2005 and Ampoorter et al., 2007).

We selected 24 of the 36 sampling plots ( 8 per stand type, randomly distributed throughout the forest) and took light measurements in September, 2013, when the leaves were fully developed. Light transmission at each subplot was measured for 24 $\mathrm{h}$ with SKP215 (Skye Instruments) sensors in the photosynthetically active radiation spectrum (PAR, 400-700 nm, in $\mu$ mol. $\mathrm{m}^{-2} . \mathrm{s}^{-1}$ ) (Balandier et al., 2006). We set one sensor $2 \mathrm{~m}$ high above the center of each subplot and placed a control sensor in an open area nearby (hemisphere free of any obstruction) to measure incident radiation. We also placed a sunshine sensor (Delta-T Devices) in the open area to assess diffused radiation and to take into account variations due to weather conditions. Hemispherical photographs were taken to compute the precise time of sunset and sunrise above the tree periphery for each sampling day (Adam et al., 2008). Light transmittance for each subplot was calculated as the ratio between daily mean PAR and daily mean incidence radiation. Light data from sunset to sunrise was omitted. The ratio of diffused to incident radiation was used to correct daily mean PAR data: $\mathrm{PAR}_{\text {correct }}=\mathrm{PAR} \times(1-($ diffused radiation/incident radiation $) \times 0.15$. This process enabled us to compare measurements made on different days (i.e. with different sun fluxes) and with different weather conditions (i.e. cloudy or sunny) (Balandier et al., 2006). Finally, relative PAR value (PAR value of each subplot divided by full light PAR) was calculated as a light availability indicator. 


\subsection{Data analysis}

We modeled the responses of a) species richness - i.e. the number of observed species in the subplot, b) the abundance of ecological groups (Table 1) and c) the abundance of individual common species (defined as those with an occurrence of $>$ $25 \%$ ) to variables that related to subplot location, soil compaction degree, stand attributes, soil moisture and light (Table 2).

We applied a total of 27 explanatory models to species richness, abundance of each ecological group (10 groups) (Table 3), and to the abundance of each individual species (15 species). Our first group of ecological models was composed of single-variable models related to subplot location, stand type, basal area, soil compaction degree (PR, MaxD, Nsam, BD) and light (models [2] to [11]). Comparing the single-variable models helped us distinguish the dominant factor on skid trails. To further detect whether ground flora diversity patterns could be better explained by the combined effects of subplot location, soil moisture, soil compaction or light with stand type or basal area, we modeled the interactive effects of subplot location and stand attributes (stand type and basal area) in the second group (models [12] and [13]), as well as the additive effects of soil compaction degree, soil moisture or light and stand type in the third group (models [14] to [20]). The four soil compaction variables (PR, Nsam, MaxD and BD) were included in parallel models from model [14] to [17]. The last group of models was composed of quadratic models related to soil compaction degree, soil moisture and light (models [21] to [27]), since in several studies, non-linear relationships between PR and plant species cover were detected (Godefroid and Koedam, 2004a). Only on the 24 plots where light measurements were taken did we compare light models (models [11], [20] and [27]) with the best ones selected from the other 24 models.

The variables (Table 2) were included in different generalized linear mixed models (GLMMs) for coefficient estimation and model comparison based on the QAICc (Quasi Akaike Information Criterion corrected for small sample size). Model comparisons based on an information criterion such as AIC make it possible to measure the relative quality of statistical models, and thus to identify the "best" model.

331 They include a trade-off between model goodness of fit and model complexity. 332 QAICc is an extension of the AIC for the analysis of count data with a level of 
dispersion different from that of the Poisson distribution, and is adapted to limited sample sizes for which the asymptotic results known for AIC do not necessarily apply (Lebreton et al., 1992). This model comparison approach was completed by an analysis of the magnitude of the estimates since model comparison techniques are much more in line with statistical significance than with "biological" significance (e.g. McQuarrie and Tsai, 1999). The lmer function (in the lme4 R package, with the default Laplace approximation to the loglikelihood, Bates and Maechler, 2010) with the Quasi-Poisson "family" was used. The link function was the default (log) for these models. A random "plot" effect was incorporated on the intercept into all the 27 models in Table 3. For QAICc, a common dispersion parameter was used for all the 27 models being compared for each group, as advocated by Bolker et al. (2009). The common dispersion parameter was taken to be that of the Quasi-Poisson model: PR + STP (where STP is stand type). Analyses based only on statistical significance $(P$-values) are unable to distinguish practically important different situations in trends. This is because, in the usual statistical tests for trends, the failure to reject the null hypothesis of no trend does not prove that the null hypothesis is true, nor does the rejection of the null hypothesis indicate whether or not the trend is ecologically important or non-negligible. The important question is actually whether the true trend is ecologically negligible or not (Dixon and Pechmann, 2005). As did Barbier et al. (2009), we distinguished, for both richness and abundance data, two levels of ecological negligibility in the multiplier of the mean of species richness and abundance - here denoted by $\beta$ - to a given increase in an ecological variable (see below): a more stringent one $\left(b_{1}\right)$, corresponding to a strict ecological negligibility and a less stringent one $\left(b_{2}\right.$, with $\left.\left(0<b_{1}<b_{2}\right)\right)$. Four different cases occur when describing negligibility effects: (1) negligible weak effects denoted by " 0 " when the value of the multiplier $(\beta)$ follows $P\left(-\mathrm{b}_{2}<\log (\beta)<\mathrm{b}_{2}\right) \geq 0.95$, and negligible very weak effects denoted by " 00 " for the more stringent $P\left(-b_{1}<\log (\beta)<b_{1}\right) \geq 0.95$; (2) non-negligible negative and very negative effects: “-” for $P\left(\log (\beta)<-b_{1}\right) \geq 0.95$ and "--" for the stronger $P\left(\log (\beta)<-\mathrm{b}_{2}\right) \geq 0.95$; (3) non-negligible positive and very positive effects: "+" for $P\left(\log (\beta)>\mathrm{b}_{1}\right) \geq 0.95$ and "++" for the stronger $P\left(\log (\beta)>\mathrm{b}_{2}\right)$ $\geq 0.95$; and (4) negligibility where the estimator cannot be classified in any of the above categories. In our analysis, we chose $b_{1}=0.1, b_{2}=0.2$ for species richness, and $b_{1}=0.25, b_{2}=0.5$ for abundance, as in Barbier et al. (2009). In other words, we considered that a change of $10 \%$ in species richness or $25 \%$ in abundance was an 
ecologically-significant change, while a change of $20 \%$ or $50 \%$ respectively was a strongly significant change (see Table A1 in Appendix). The increases in the continuous ecological variables we considered were of about one standard deviation: 0.5 MPa for increment for PR, 1 for Nsam, $10.5 \mathrm{~cm}$ for MaxD, $0.25 \mathrm{~g} . \mathrm{cm}^{-3}$ for BD, $6.5 \%$ for moisture, $6 \mathrm{~m}^{3} \cdot \mathrm{cm}^{-3}$ for WCS and $5 \mathrm{~m}^{2} \cdot \mathrm{ha}^{-1}$ for basal area. For stand type (STP), we calculated the associated multiplicative coefficient by supposing the stand changed from one type to the successive type: STP30 to STP50 stands (STP30to50), and STP50 to STP63 stands (STP50to63). The multiplicative coefficient for subplot location was obtained by calculating the difference between the subplot locations and the control (COtoBE, COtoTR and COtoBO). For quadratic models, we obtained the multiplicative coefficient for the same variation as above but calculated at first, second and third quartile of the explanatory variable. We report the mean value of the multiplier for each variable and its $95 \%$ confidence interval.

We analyzed the magnitude of the effects of the best models (the lowest QAICc) on the richness and abundance of each ecological group, as well as on the abundance of each species (occurrence $>25 \%$, Table A2). The bootstrap resampling method from the R boot library allowed us to obtain reliable samples of the coefficients in the models, at both the ecological group and species levels, based on 10,000 simulations (Stine, 1990). The bootstrap method resamples the original data with replacement, calculates the index of interest from each bootstrap sample, and estimates the mean, confidence interval and standard error from the replicate bootstrap estimates (Mueller and Altenberg, 1985 and Krebs, 1989).

We used generalized linear models (GLMs) with the Gaussian "family" to assess the association between the different soil compaction indicators (PR, Nsam, MaxD and BD) and the variations in soil compaction, soil moisture and light among subplot locations and stand types.

\section{Results}

\subsection{Fine-scale variation of environmental factors}

PR was significantly greater on wheel tracks (TR) than on controls in STP50 and STP63 and between the two wheel tracks (BE) in STP63 $(P<0.001)$ (Fig. 2). Nsam 
and BD were also significantly higher on TR in STP63. PR, Nsam and BD on the subplot locations BE and TR increased with the increasing age of the stands. No significant variation in MaxD among subplot locations was detected (Fig. 2). BD, Nsam and MaxD were significantly associated to PR $(P<0.001)$. Light and soil moisture did not vary among subplot locations whatever the stand type (Fig. 3), but did vary among stand types $(P<0.001)$.

\subsection{Best models}

The best models fell into two broad categories (Table 3): models related to subplot locations that indirectly represent the disturbance gradient and models related to micro-site factors of soil compaction degree, soil moisture or light.

For richness (Table 4), among the 10 ecological groups, two (trees and short-term seed bank species) had best models related to the interactive effects of subplot location and stand type; four groups (herbaceous, shrub, long-term seed-bank and heliophilous species) were best related to soil compaction indices ( $\mathrm{PR}, \mathrm{MaxD}$ or $\mathrm{BD}$ ), and four groups (transient seed bank, high-humidity, low-humidity and shade-tolerant species) to soil moisture.

For abundance data (Table 5), three groups (long-term seed bank, high-humidity, shade-tolerant species) had best models related to subplot location; two groups (tree, heliophilous species) were related to the interaction between subplot location and basal area; three groups (shrub, Low-humidity, transient seed-bank species) were related to PR, and two groups (herbaceous and short-term seed bank species) to soil moisture. Light-only (L) models were preferred to alternative models for heliophilous species richness and long-term seed-bank species abundance (Table 6). The quadratic models combining light and stand type performed the best for herbaceous species richness.

\subsection{Magnitude of the effects}

For richness data, the magnitude and negligibility of the effects estimated from the best models are shown in Tables 4 and 6. Subplot locations of BE and TR had positive 
effects on tree and short-term seed bank species in STP50, as did the subplots of BE, TR and BO on tree and short-term seed bank species in STP63. Soil moisture showed positive effects on the richness of all the ecological groups with best models related to soil moisture (transient seed bank, low-humidity, high-humidity and shade-tolerant species). For compaction indicators, BD had a positive effect on heliophilous species richness. The effect of MaxD was either weak (long-term seed bank species) or uncertain (shrubs). PR effect was also weak (herbaceous species). The effect of light was either weak (herbaceous species) or uncertain (heliophilous species). The transition of stand type from STP30 to STP50 had a negative effect on shrubs in the additive models of MaxD and STP, while it had a positive effect on herbaceous species richness in the additive models of PR and STP. The transition of stand type from STP50 to STP63 had a positive effect on herbaceous species richness in the quadratic model combining light and stand type.

For abundance data (Tables 5 and 6), TR and BE respectively had a positive effect on shade-tolerant and tree species. Soil moisture had a positive effect on short-term seed bank species, whereas its effect on herbaceous species was weak. Similarly, PR had a positive effect on shrubs and a weak effect on transient seed bank species; its effect on low-humidity species was uncertain. The effect of light was weak on long-term seed bank species. The transition of stand type from STP30 to STP50 had a positive effect on herbaceous species and a weak effect on transient seed bank species in the quadratic model combing soil moisture and stand type, while the effect of the transition from stand type STP50 to STP63 on herbaceous transient seed bank species was weak. Basal area had a weak effect on trees and heliophilous species in the models combining subplot and basal area.

\section{Discussion}

\subsection{Best models for ecological groups}

Disturbance, soil moisture, soil compaction, light, stand type and basal area have been found to be important factors impacting understory diversity (Skov, 1997, Nagaike et al., 2005, Barbier et al., 2008 and Sciama et al., 2009), but few studies have compared the relative importance of these variables to detect which one(s) might be the best indicator(s) under the multiple hypotheses framework (Chamberlin, 
1965). In our study, we used a model comparison approach to determine the best indicators of ground flora diversity. For the majority of the ecological groups we studied ( 8 out of 10 groups), the best indicators of species richness were related to micro-environmental factors. Abundance was best indicated by models related to subplot location for half of the groups (5 out of 10) and by micro-environmental factors for the other half (Tables 4 and 5).

\subsection{Dominant factors affecting ground flora diversity on skid trails}

In our study, subplot location, soil moisture and soil compaction played non-negligible dominant roles at the fine scale in stands managed with a skid trail system. The dominant effects depended on the ecological group studied and on whether species richness or species abundance was considered. We agree with Brosofske et al. (2001) that disturbance can sometimes override environmental influences. Subplot location, which indirectly represents the disturbance gradient, was the best indicator that showed non-negligible effects on the richness of tree and short-term seed bank species, as well as for the abundance of tree species and shade-tolerant species. However, the effects of subplot location depended on stand types: its positive effects only occurred in the two older stand types. Skid trails in the youngest stands were denser but narrower than in the older stands, and were submitted to fewer and/or less intense disturbances. Indeed, soil compaction values that were significantly higher on skid trails than on the paired forest controls were observed only in the two older stand types (Fig. 2). Furthermore, community stability reflects the ability of resident species to resist change, or, if altered by disturbance, their ability to readjust or recover (Halpern, 1988). Following these criteria, the understory plant community in our research area appears to be resilient to the skid trail system. Skid trails did not appear to negatively impact ground flora diversity. On the contrary, it promoted the diversity of some ecological groups.

Soil moisture was the best indicator for the richness of transient seed bank, shade-tolerant, low- and high- humidity species, as well as the abundance of short-term seed bank species. In our study, soil moisture levels varied significantly among stand types, but did not vary along the disturbance gradient in each stand type. Ezzati et al. (2012) obtained a similar finding: there was no moisture difference between skid trail and undisturbed forest 16 to 20 years after skidding operations. 
According to our results, richness of both low- and high- humidity species was positively affected by soil moisture. As explained by Qian et al. (1997), the trend toward higher diversity in wetter soil conditions generally agrees with findings that diversity peaks at mesic sites (e.g. Burton et al., 1992, Pausas, 1994 and Roberts and Gilliam, 1995).

Our study supports the important role of soil compaction only for shrubs abundance (with PR as the best indicator) and heliophilous richness (with $\mathrm{BD}$ as the best indicator). Higher soil compaction detected on skid trails does not necessarily mean that it will have significant effects on ground flora. One reason may be that the soil compaction levels in our study were not high enough to affect ground flora. This was supported by Zenner et al. (2007) who found that, though traffic intensity had a negative effect on both aspen density and growth, PR measured from this traffic was not significantly associated with aspen density and growth. Zenner et al. (2007) explained that the PR values after harvest were below the levels that restrict the suckering and growth of aspen. Specific PR values at which root growth is restricted are thought to be between 2,500 and 3,000 kPa for many plant species (Taylor et al., 1966 and Greacen and Sands, 1980). In our study, the critical value of 2,500 kPa was found only on the wheel tracks (TR) in stands aged 50 and 63 years. Heninger et al. (2002) used BD as a soil compaction indicator and found that reductions in tree height were unrelated to percentage increases in soil bulk density in the 0 to $30 \mathrm{~cm}$ soil horizon. For the four soil compaction indicators we studied (PR, Nsam, MaxD and $\mathrm{BD}$ ), we found that $\mathrm{PR}$ and $\mathrm{BD}$ were better soil compaction indicators of floristic biodiversity than Nsam and MaxD. PR and BD were more sensitive than Nsam and MaxD to the variation in degree of soil compaction. In addition, only PR and BD were found to have non-negligible effects on ground flora diversity. Higher soil moisture is usually considered to result in more compacted soils (Williamson and Neilsen, 2000 and McNabb et al., 2001), and vice versa (Greacen and Sands, 1980 and Tan et al., 2005). However, in our study, there was no strong relationship between $\mathrm{PR}$ and moisture (Pearson's $\mathrm{r}=0.148, P=0.0898$ ). More ecological groups were affected by soil moisture than by soil compaction. Only one study to our knowledge compared the effects of soil moisture and compaction at the stand scale, and found that seedling growth rate in the periods $0-12$ and 12-24 months after planting was promoted by higher soil moisture (33\%), while PR had no effect (Hattori et al., 2013). 
534 to detect any significant effects of canopy removal intensity on ground flora composition and diversity on plots covered with skid trails. Light did not vary among subplot locations in any stand type in our study. In fact, decades after the creation of skid trails, nearby trees are already tall enough for canopy cover to be fully developed even with disturbance. This was the case even in the youngest stands (30 years on average) we studied because, although the trees were relatively smaller and denser, the skid trails were narrower and the machines used were smaller than in the older stands. Buckley et al. (2003) also found that mean canopy cover was only slightly lower on skid trails than in the forest interior.

\subsection{Responses of ecological groups to their best indicators}

In our study, the species richness of tree seedlings and saplings was higher on skid trails than in the forest interior (Table 4). The positive role of skid trails on tree recruitment, growth and seedling density has already been repeatedly evidenced in previous studies (Roberts and Harrington, 2008 and Swaine and Agyeman, 2008). A more innovative finding is that the positive influence of skid trails on tree species richness depended on forest type - higher richness on skid trails only occurred in the older stands (50 and 63 year-old) but not in the youngest stands (30 year-old) (Table 4). This is because with increasing stand age, the richness of tree seedlings and saplings progressively decreased on controls but did not change on skid trails. For the other two life-form groups (shrubs and herbaceous species), soil compaction has been found to respectively reduce herbaceous cover and increase shrub richness and cover in large plots $\left(60 \mathrm{~m}^{2}\right)$ (Zenner and Berger, 2008). Our study also demonstrated a positive effect of soil compaction on shrub abundance at a finer scale. Though the model combining soil compaction and stand type was the best for herbaceous richness, the strongest positive effect was due to the ageing of the stand (from 30 to 50 years), while the effect of soil compaction was weak.

Species producing a large number of persistent seeds (alive in seed banks for $\geq 1$ year, defined by Thompson and Grime, 1979) seem to be favored by recurring disturbance cycles such as flooding, burning or tree falls; they are awaiting favorable conditions for germination in the soil (van der Valk and Davis, 1978, Thompson and Grime, 1979 and Pugnaire and Lázaro 2000;). As another form of recurring disturbance, man-made skid trails were found to maintain a higher diversity of species 
with short-term persistent seeds (Avon et al., 2013), which is what we observed in the stands aged 50 and 63 years but not in the younger stands. For transient seed bank species, the dominant factor affecting richness was soil moisture rather than skid trail disturbance.

Concerning light-demanding groups, we found a higher abundance of shade-tolerant species on skid trails. Toledo-Aceves et al. (2009) also found that even shade-tolerant species displayed higher densities on skid trails in comparison with closed canopy conditions. Conversely, Avon et al. (2013) found a higher richness of shade-tolerant species in stand interiors and more heliophilous species on skid trails. For heliophilous species richness, BD was a better indicator - associated with a positive non-negligible effect -than light or subplot location. Concerning ecological groups classified by soil moisture, we found that richness for both low- and high-humidity species increased with increasing moisture on skid trails. No previous studies had detected the effects of skid trails on moisture groups.

\subsection{Conclusion}

Mechanized harvesting in France is relatively recent and harvesting with heavier machines is likely to occur in the future. Our current study was conducted on plots in relatively young stages in the forestry cycle (30 to 63 years). Investigating skid trail effects in older stands ( $>63$ years) and even younger stands ( $<30$ years) should be considered.

Our study compared the effects of skid trail disturbance (represented by subplot location) and micro-environmental factors (light, soil moisture and compaction) on ground flora diversity at a fine scale. The Montargis forest contains two types of parallel skid trails: primary and secondary skid trails. The primary skid trails are mainly used for removing shrubs inside the stand, while the secondary skid trails are mainly for cutting and extracting wood from the forest interior. Not only did we observe that soil compaction was higher on secondary skid trails compared to the forest interior, we also found that compaction on secondary skid trails increased with stand age. The other two environmental factors - light and soil moisture - were not affected by skid trail disturbance. Skid trail disturbance, soil moisture and soil compaction were the best indicators, showing non-negligible effects on ground flora. 
601

602

603

604

605

606

607

608

609

610

611

612

613

614

615

616

617

618

619

620

621

622

623

624

625

626

627

628

629

630

631

632

633

However, skid trail disturbance only had non-negligible effects in stands with secondary skid trails.

Our research was confined to high forest and covered a relatively narrow range of stand ages (30 to 63 years old, i.e. about one sixth of a typical 180-to-200-year rotation). However, we still detected a difference in skid trail effects on plant diversity among stand types. Furthermore, the species groups favored by skid trail conditions were native species (e.g. tree seedlings/saplings, short-term seed bank species) rather than non-native species. This means that skid trails are not systematically a source of exoticspecies. We also checked whether the native species favored by skid trails included competitive species which might potentially limit tree regeneration (Table A2 in Appendix). Rubus fruticosus was the only species more abundant on skid trails compared to controls that is known to reduce tree growth (e.g. Schreiner et al, 2000). Even though, in our case, skid trails also favored tree diversity, we cannot reject the hypothesis that skid trails might accelerate the development of $R$. fruticosus at the expense of tree seedlings during the regeneration phase in high forest stands.

Unlike coppice-with-standards (CWS) where frequent coppice cuttings conserve the diversity of many functional species groups such as vernal, heliophilous and seed banking species (Ash and Barkham, 1976, Van Calster et al., 2007 and Baeten et al., 2009), the maturing process of high forest stands was found to be accompanied by a generalized decrease in ground flora diversity (Chevalier, 2003); Duguid and Ashton, 2013). Yet, according to our results, skid trails could have a positive effect in this respect: while floristic biodiversity did progressively decline within stands, skid trails seemed to allow at least some components of ground flora diversity to maintain a constant level of plant diversity in young to mature high forests. The species favored by skid trails may then be able to recolonize the stand following natural disturbances or cuttings.

\section{Acknowledgements}

This work was supported by the French ministry in charge of Ecology through the DEB-Irstea convention (Action B - GNB Sol) and by the China Scholarship Council (CSC). We thank Vicki Moore for correcting the English. 
634

635

636

637

638

639

640

641

642

643

644

645

646

647

648

649

650

651

652

653

654

655

656

657

658

659

660

661

\section{References}

Adam B., Sinoquet H., Balandier P., Marquier A., 2008. PiafLA - software to calculate transmitted light by canopies. Version 1.0. UMR PIAF INRA-UBP, Clermont-Ferrand.

Akbarimehr, M., Jalilvand, H., 2013. Considering the relationship of slope and soil loss on skid trails in the north of Iran (a case study). J. For. Sci. 59, 339-344.

Ampoorter, E., Goris, R., Cornelis, W.M., Verheyen, K., 2007. Impact of mechanized logging on compaction status of sandy forest soils. For. Ecol. Manage. 241, $162-174$.

Ampoorter, E., Van Nevel, L., De Vos, B., Hermy, M., Verheyen, K., 2010. Assessing the effects of initial soil characteristics, machine mass and traffic intensity on forest soil compaction. For. Ecol. Manage. 260, 1664-1676.

Ash, J.E., Barkham, J.P., 1976. Changes and variability in the field layer of a coppiced woodland in Norfolk, England. J. Ecol. 64, 697-712.

Augusto, L., Dupouey, J.L., Ranger, J., 2003. Effects of tree species on understory vegetation and environmental conditions in temperate forests. Ann. For. Sci. 60, $823-831$.

Avon, C., Dumas, Y., Berges, L., 2013. Management practices increase the impact of roads on plant communities in forests. Biol. Conserv. 159, 24-31.

Baeten, L., Bauwens, B., De Schrijver, A., De Keersmaeker, L., Van Calster, H., Vandekerkhove, K., Roelandt, B., Beeckman, H., Verheyen, K., 2009. Herb layer changes (1954-2000) related to the conversion of coppice-with-standards forest and soil acidification. Appl. Veg. Sci. 12, 187-197.

Balandier, P., Sonohat, G., Sinoquet, H., Varlet-Grancher C., Dumas Y., 2006. Characterisation, prediction and relationships between different wavebands of solar radiation transmitted in the understorey of even-aged oak (Quercus petraea, Q. robur) stands. Trees $20,363-370$. 
662 Barbier, S., Chevalier, R., Loussot, P., Berges, L., Gosselin, F., 2009. Improving 663 biodiversity indicators of sustainable forest management: Tree genus abundance 664 rather than tree genus richness and dominance for understory vegetation in 665 French lowland oak hornbeam forests. For. Ecol. Manage. 258, S176-S186.

666 Barbier, S., Gosselin, F., Balandier, P., 2008. Influence of tree species on understory 667

Bates, D.M., Maechler, M., 2010. lme4: Linear mixed-effect models using S4 classes. R package version 0.999375-34 [Software]. Vienna, Austria: R Foundation for Statistical Computing.

Beaudet, M., Angers, V.A., Messier, C., 2014. Seedbed proportions in and outside skid trails: Temporal variation following selection cutting in northern hardwood forests. For. Ecol. Manage. 318, 151-157.

Beckage, B., Clark, J.S., Clinton, B.D., Haines, B.L., 2000. A long-term study of tree seedling recruitment in southern Appalachian forests: the effects of canopy gaps and shrub understories. Can. J. For. Res. 30, 1617-1631.

Berger, A.L., Puettmann, K.J., Host, G.E., 2004. Harvesting impacts on soil and understory vegetation: the influence of season of harvest and within-site disturbance patterns on clear-cut aspen stands in Minnesota. Can. J. For. Res. 34, 2159-2168.

Brunet, J., Falkengren-Grerup, U., Tyler, G., 1996. Herb layer vegetation of south 683

Burton, P.J., Balisky, A.C., Coward, L.P., Cumming, S.G. and Kneeshaw, D.D., 1992. The value of managing for biodiversity. For. Chron. 68, 225-237.

Burton, J.I., Mladenoff, D.J., Clayton, M.K., Forrester, J.A., 2011. The roles of 689 environmental filtering and colonization in the fine-scale spatial patterning of ground-layer plant communities in north temperate deciduous forests. J. Ecol. 99, 764-776. 
691 Bolker, B.M., Brooks, M.E., Clark, C.J., Geange, S.W., Poulsen, J.R., Stevens, 692 M.H.H., White, J.S.S., 2009. Generalized linearmixed models: a practical guide 693 for ecology and evolution. Trends Ecol. Evol. 24, 127-135.

694 Brosofske, K.D., Chen, J., Crow, T.R., 2001. Understory vegetation and site factors: 695 implications for a managed Wisconsin landscape. For. Ecol. Manage. 146, $696 \quad 75-87$.

697 Buckley, D.S., Crow, T.R., Nauertz, E.A., Schulz, K.E., 2003. Influence of skid trails 698 and haul roads on understory plant richness and composition in managed forest 699 landscapes in Upper Michigan, USA. For. Ecol. Manage. 175, 509-520.

Cassel, D.K., 1982. Tillage effects on soil bulk density and mechanical impedance, 701 properties and processes. ASASSSA, Madison, USA, pp. 45-67.

Chamberlin, T.C., 1965. The method of multiple working hypotheses. Science 148, $754-759$.

Chevalier, R., 2003. Sylviculture du Chêne et biodiversité végétale spécifique. Étude d'une forêt en conversion vers la futaie régulière: la forêt domaniale de Montargis (45). Mémoire pour l'obtention du diplôme de l'École Pratique des Hautes Études Thesis, Cemagref, Nogent-sur-Vernisson.

Dixon, P.M., Pechmann, J.H.K., 2005. A statistical test to show negligible trend. Ecology 86, 1751-1756.

Duguid, M.C., Ashton, M.S., 2013. A meta-analysis of the effect of forest management for timber on understory plant species diversity in temperate forests. For. Ecol. Manag. 303, 81-90.

Ellenberg H., Weber H. E., Düll R., Wirth W., Werner W. \& Paulissen D. (1992): Zeigerwerte von Pflanzen in Mitteleuropa. Ed. 2. Scr. Geobot. 18: 1-258.

Ezzati, S., Najafi, A., Rab, M.A., Zenner, E.K., 2012. Recovery of Soil Bulk Density, Porosity and Rutting From Ground Skidding Over a 20-Year Period after Timber Harvesting in Iran. Silva Fenn. 46, 521-538. 
Franzen, H., Lal, R., Ehlers, W., 1994. Tillage and mulching effects on physical properties of a tropical Alfisol. Soil Till. Res. 28, 329-346.

Gilliam, F.S., 2002. Effects of harvesting on herbaceous layer diversity of a central Appalachian hardwood forest in West Virginia, USA. For. Ecol. Manag. 155, $33-43$.

Gliński, J., Lipiec, J., 1990. Soil Physical Conditions and Plant Roots. CRC Press, Boca Raton, Florida, USA.

Godefroid, S., Koedam, N., 2004a. Interspecific variation in soil compaction sensitivity among forest floor species. Biol. Conserv. 119, 207-217.

Godefroid, S., Koedam, N., 2004b. The impact of forest paths upon adjacent vegetation: effects of the path surfacing material on the species composition and soil compaction. Biol. Conserv. 119, 405-419.

Gray, A.N., Spies, T.A., Pabst, R.J., 2012. Canopy gaps affect long-term patterns of tree growth and mortality in mature and old-growth forests in the Pacific Northwest. For. Ecol. Manage. 281, 111-120.

Greacen, E.L., Sands, R., 1980. Compaction of forest soils - a review. Aust. J. Soil Res. 18, 163-189.

Hattori, D., Kenzo, T., Inino, K.O., Kendawang, J.J., Ninomiya, I., Sakurai, K., 2013. Effects of soil compaction on the growth and mortality of planted dipterocarp seedlings in a logged-over tropical rainforest in Sarawak, Malaysia. For. Ecol. Manage. 310, 770-776.

Halpern, C.B., 1988. Early successional pathways and the resistance and resilience of forest communities. Ecology 69, 1703-1715.

Hammond, P.C., Miller, J.C., 1998. Comparison of the biodiversity of Lepidoptera within three forested ecosystems. Ann. Entomol. Soc. Am. 91, 323-328.

Heninger, R., Scott, W., Dobkowski, A., Miller, R., Anderson, H., Duke, S., 2002. Soil disturbance and 10-year growth response of coast Douglas-fir on nontilled and tilled skid trails in the Oregon Cascades. Can. J. For. Res. 32, 233-246. 
Helms, J. (Ed.), 1998. The Dictionary of Forestry. Society of American Foresters. Bethesda, MD, USA.

Hodgson, J.G., Grime, J.E., Hunt, R., Thompson K., 1995. The electronic comparative plant ecology. Chapman \& Hall, London, UK.

Horn, H.S., 1971. The adaptive geometry of trees. Princeton University Press, Princeton, New Jersey, USA.

Jarret, P., 2004. Guide des sylvicultures. Chênaie atlantique. Lavoisier - Office National des Forêts.

Julve, P., 2007. Baseflor. Index botanique, écologique et chorologique de la flore de France. (http://perso.orange.fr/philippe.julve/catminat.htm)

Krebs, C.J., 1989. Ecological Methodology. Harper and Row Publishers, New York, USA.

Krzic, M., Newman R.F., Broersma. K., 2003. Plant species diversity and soil quality in harvested and grazed boreal aspen stands of northeastern British Columbia. For. Ecol. Manage. 182, 315-325.

Leibold, M.A., Holyoak, M., Mouquet, N., Amarasekare, P., Chase, J.M., Hoopes, M.F., Holt, R.D., Shurin, J.B., Law, R., Tilman, D., Loreau, M., Gonzalez, A., 2004. The metacommunity concept: a framework for multiscale community ecology. Ecol. Lett. 7, 601-613.

Lebreton, J.D., Burnham, K.P., Clobert, J., Anderson, D.R., 1992. Modeling survival and testing biological hypotheses using marked animals: a unified approach with case studies. Ecol. Monogr. 62, 67-118.

Liechty, H.O., Shelton, M.G., Luckow, K.R., Turton, D.J., 2002. Impacts of shortleaf pine-hardwood forest management on soils in the Ouachita Highlands: A review. South. J. Appl. For. 26, 43-51.

McGill, B.J., Enquist, B.J., Weiher, E., Westoby, M., 2006. Rebuilding community ecology from functional traits. Trends Ecol. Evol. 21, 178-185.

McQuarrie, A., Tsai, C.L., 1999. Model selection in orthogonal regression. Stat. Probabil. Lett. 45, 341-349. 
McNabb, D.H., Startsev, A.D., Nguyen., H., 2001. Soil wetness and traffic effect levels on bulk density and air- field porosity of compacted boreal forest soils. Soil Sci. Soc. Am. J. 65, 1238-1247.

Meier, A.J., Bratton, S.P., Duffy, D.C., 1995. Possible ecological mechanisms for loss of vernal-herb diversity in logged eastern deciduous forests. Ecol. Appl. 5, 935-946.

Metzger, F., Schultz, J., 1984. Understory response to 50 years of management of a northern hardwood forest in Upper Michigan. AM. Midl. Nat. 112, 209-223.

Miller, J.H., Sirois., D.L., 1986. Soil disturbance by skyline yarding vs skidding in a loamy hill forest. Soil Sci. Soc. Am. J. 50, 1579-1583.

Miller, R.E., Hazard, J., Howes, S., 2001, Precision, accuracy, and efficiency of four tools for measuring soil bulk density or strength. USDA Forest Service, PNWRS, pp. 23.

Mueller, L.D., Altenberg, L., 1985. Statistical Inference on Measures of Niche Overlap. Ecology 66, 1204-1210.

Nagaike, T., Kamitani, T., Nakashizuka, T., 2005. Effects of different forest management systems on plant species diversity in a Fagus crenata forested landscape of central Japan. Can. J. For. Res. 35, 2832-2840.

Naghdi, R., Bagheri, I., Basiri, R., 2010. Soil disturbances due to machinery traffic on steep skid trail in the north mountainous forest of Iran. J. For. Res. 21, 497-502.

ONF, 1996, Révision d'aménagement. Forêt domaniale de Montargis (4090,42 ha). Département du Loiret. 1996-2015. ONF, pp. 120.

Pausas, J.G., 1994. Species richness patterns in the understory of Pyrenean Pinus sylvestris forest. J. Veg. Sci. 5, 517-524.

Picchio, R., Neri, F., Petrini, E., Verani, S., Marchi, E., Certini, G., 2012. Machinery-induced soil compaction in thinning two pine stands in central Italy. For. Ecol. Manage. 285, 38-43. 
804 Planchais, I., Sinoquet, H., 1998. Foliage determinants of light interception in sunny 805 and shaded branches of Fagus sylvatica (L.). Agr. Forest Meteorol. 89, 241-253. 806 Pregitzer, K.S., Barnes, B.V., 1982. The use of ground flora to indicate edaphic 807 factors in upland ecosystems of the mccormick-experimental-forest, Upper 808 Michigan. Can. J. Forest. Res. 12, 661-672.

809 Pugnaire F.I., Lázaro R., 2000. Seed bank and understorey species composition in a 810 semi-arid environment, the effect of scrub age and rainfall. Ann. Bot. 86, $811 \quad 807-813$.

812 Qian, H., Klinka, K., Sivak, B., 1997. Diversity of the understory vascular vegetation 813 in 40 year-old and old-growth forest stands on Vancouver Island, British 814 Columbia. J. Veg. Sci. 8, 773-780.

815 Roberts, M.R., Gilliam, F.S., 1995. Disturbance effects on herbaceous layer 816 vegetation and soil nutrients in Populus forests of northern lower Michigan. J. $817 \quad$ Veg. Sci. 6, 903-912.

818 Roberts, S.D., Harrington, C.A., 2008. Individual tree growth response to 819 variable-density thinning in coastal Pacific Northwest forests. For. Ecol. Manage. $820 \quad 255,2771-2781$.

821 Roovers, P., Baeten, S., Hermy, M., 2004. Plant species variation across path 822 ecotones in a variety of common vegetation types. Plant Ecol. 170, 107-119.

823 Schack-Kirchner, H., Fenner, P.T., Hildebrand, E.E., 2007. Different responses in 824 bulk density and saturated hydraulic conductivity to soil deformation by logging machinery on a Ferralsol under native forest. Soil Use Manage. 23, 286-293.

Sciama, D., Augusto, L., Dupouey, J.L., Gonzalez, M., Dominguez, C.M., 2009. Floristic and ecological differences between recent and ancient forests growing on non-acidic soils. For. Ecol. Manage. 258, 600-608.

Skov, F., 1997. Stand and neighbourhood parameters as determinants of plant species richness in a managed forest. J. Veg. Sci. 8, 573-578. 
831 Smith, C.W., Johnston, M.A., Lorentz, S., 1997. The effect of soil compaction and 832 soil physical properties on the mechanical resistance of South African forestry $833 \quad$ soils. Geoderma 78, 93-111.

834 Solgi, A., Najafi, A., 2014. The impacts of ground-based logging equipment on 835 forest soil, J. For. Sci. 60, 28-34.

836 Stine, R., 1990. An introduction to bootstrap methods. Sociol. Method. Res. 18, $243-291$.

Swaine, M.D., Agyeman, V.K., 2008. Enhanced tree recruitment following logging in two forest reserves in Ghana. Biotropica 40, 370-374.

Tan, X., Scott, X.C., Kabzems, R., 2005. Effects of soil compaction and forest floor removal on soil microbial properties and $\mathrm{N}$ transformations in a boreal forest long-term soil productivity study. For. Ecol. Manage. 217, 158-170.

Taylor, H.M., Roberson, G.M., Parker Jr., J.J., 1966. Soil strength-root penetration relations to medium to coarse-textured soil materials. Soil Sci. 102, 18-22.

Thomas, S.C., Halpern, C.B., Falk, D.A., Liguori, D.A., Austin, K.A., 1999. Plant diversity in managed forests: understory responses to thinning and fertilization. Ecol. Appl. 9, 864-879.

Thompson, K., Grime, J.P., 1979. Seasonal variation in the seed banks of herbaceous species in ten contrasting habitats. J. Ecol. 67, 893-921.

Toledo-Aceves, T., Purata-Velarde, S., Peters, C.M., 2009. Regeneration of commercial tree species in a logged forest in the Selva Maya, Mexico. For. Ecol. Manage. 258, 2481-2489.

Van der Valk, A.G., Davis., C.B., 1978. The role of seed banks in the vegetation dynamics of prairie glacial marshes. Ecology 59, 322-335.

Vaz, C.M.P., Luis, H.B., Hopmans, J.W., 2001. Contribution of water content and bulk density to field soil penetration resistance as measured by a combined cone penetrometer-TDR probe. Soil Till. Res. 60, 35-42.

Wender, B.W., Hood, S.M., Smith, D.W., Zedaker, S.M., Loftis, D.L.,Haywood, J.D.,1999. Response of vascular plant communities to harvest in southern 
Appalachian mixed-oak forests: two-year results. In: J. D. Haywood (Ed.), Proceedings of the tenth Biennial Southern Silvicultural Research Conference. USDA Forest Service, Asheville, pp. 34-38.

Whalley, W.R., Leeds-harrison, P.B., Clark, L.J., Gowin, D.J.G., 2005. Use of effective stress to predict the penetrometer resistance of unsaturated agricultural soils. Soil Till. Res. 84, 18-27.

Williamson, J.R., Neilsen, W.A., 2000. The influence of forest site on rate and extent of soil compaction and profile disturbance of skid trails during ground-based harvesting. Can. J. For. Res. 30, 1196-1205.

Wolf, A.T., Parker, L., Fewless, G., Corio, K., Sundance, J., Howe, R., Gentry, H., 2008. Impacts of summer versus winter logging on understory vegetation in the Chequamegon-Nicolet National Forest. For. Ecol. Manage. 254, 35-45.

Van Calster, H., Baeten, L., De Schrijver, A., De Keersmaeker, L., Rogister, J.E., Verheyen, K., Hermy, M., 2007. Management driven changes (1967-2005) in soil acidity and the understorey plant community following conversion of a coppice-with-standards forest. For. Ecol. Manage. 241, 258-271.

Zenner, E.K., Fauskee, J.T., Berger, A.L., Puettmann, K.I., 2007. Impacts of skidding traffic intensity on soil disturbance, soil recovery, and aspen regeneration in north central Minnesota. North. J. Appl. For. 24, 177-183.

Zenner, E.K., Berger, A.L., 2008. Influence of skidder traffic and canopy removal intensities on the ground flora in a clearcut-with-reserves northern hardwood stand in Minnesota, USA. For. Ecol. Manage. 256, 1785-1794. 
Table 1 Summary of ecological groups

\begin{tabular}{|c|c|c|}
\hline Species trait & Categories & Description \\
\hline \multirow[t]{3}{*}{ Life form } & Tree & \\
\hline & Shrub & \\
\hline & Herbaceous & \\
\hline \multirow[t]{3}{*}{$\begin{array}{l}\text { Seed bank } \\
\text { persistence }\end{array}$} & Transient & $\begin{array}{l}\text { 1: present during the summer and germinating } \\
\text { synchronously in autumn, } 2 \text { : present during the winter } \\
\text { and germinating synchronously in late winter or } \\
\text { spring }\end{array}$ \\
\hline & $\begin{array}{l}\text { Short-term } \\
\text { persistence }\end{array}$ & $\begin{array}{l}3:>5 \text { years but concentrations of seeds in the soil are } \\
\text { only high after seeds have just been shed }\end{array}$ \\
\hline & $\begin{array}{l}\text { Long-term } \\
\text { persistence }\end{array}$ & $\begin{array}{l}\text { 4: a large bank of long-persistent seeds in the soil } \\
\text { throughout the year }\end{array}$ \\
\hline \multirow[t]{2}{*}{ Light } & Shade-tolerant & Ellenberg $L$ value : 2, 3, 4 \\
\hline & Heliophilous & Ellenberg $L$ value : $5,6,7,8$ \\
\hline \multirow[t]{2}{*}{ Soil moisture } & Low-moisture & Ellenberg F value : 4 \\
\hline & High-moisture & Ellenberg F value : $5,6,7,8$ \\
\hline
\end{tabular}

Data source: Hodgson et al., 1995; Julve, 2007. Ellenberg L value: Ellenberg indicator value of light (Ellenberg et al., 1992); Ellenberg F value: Ellenberg indicator value of soil moisture. The scale value 1 refers to the lowest value of the factor (e.g. very shady for L or very dry for F), and the scale value 9 to the highest value (e.g. full light for L or very wet for F)" 
Table 2 Ecological variables used in the models

\begin{tabular}{|c|c|c|}
\hline Variable & Description & Mean / SD \\
\hline Subplot.location & $\begin{array}{l}\text { Subplot location: BE: between the two tracks of a skid trail, TR: on the track in a skid trail, BO: on } \\
\text { the forest border next to the trail of a skid trail, CO: control, undisturbed habitat, in the forest } \\
\text { halfway between two parallel skid trails) }\end{array}$ & --- \\
\hline STP & $\begin{array}{l}\text { Stand type: } 3 \text { even-aged high forest stand types with a mean age of 30, } 50 \text { and } 63 \text { years (STP30, } \\
\text { STP50, STP63) (year) }\end{array}$ & --- \\
\hline G & Basal area at breast height of all the trees in a stand $\left(\mathrm{m}^{2} / \mathrm{ha}\right)$ & $28.21 / 6.41$ \\
\hline PR & Mean penetration resistance from 0 to $20 \mathrm{~cm}$ in depth $(\mathrm{MPa})$ & $1.95 / 0.66$ \\
\hline Nsam & Number of PR measurements per subplot (proxy for stone and root density) & $1.34 / 0.81$ \\
\hline Moisture & Soil moisture $(\%)$ & $23.58 / 6.47$ \\
\hline $\mathrm{BD}$ & Bulk density at a depth of between $7.5 \mathrm{~cm}$ and $12.5 \mathrm{~cm}\left(\mathrm{~g} / \mathrm{cm}^{3}\right)$ & $1.07 / 0.26$ \\
\hline WCS & Water content of $\mathrm{BD}\left(\mathrm{cm}^{3} / \mathrm{cm}^{3}\right)$ & $19.58 / 5.95$ \\
\hline $\mathrm{L}$ & Relative photosynthetic active radiation (PAR) value $(\%)$ & $1.84 / 1.91$ \\
\hline $\operatorname{MaxD}$ & Maximum depth of probe $(\mathrm{cm})$ & $47.33 / 10.45$ \\
\hline
\end{tabular}


Table 3 Summary of ecological models

\begin{tabular}{|c|c|}
\hline Effect & Models \\
\hline & [1] Null model \\
\hline Single-variable models & $\begin{array}{l}\text { [2-11] Subplot.location, STP, G, PR, MaxD, Nsam, moisture, } \\
\text { BD, WCS, L }\end{array}$ \\
\hline \multirow[t]{2}{*}{ Interactive models } & [12] subplot.location $*$ STP \\
\hline & [13] subplot.location $* \mathrm{G}$ \\
\hline \multirow[t]{7}{*}{ Additive models } & {$[14] \mathrm{PR}+\mathrm{STP}$} \\
\hline & [15] MaxD + STP \\
\hline & [16] Nsam + STP \\
\hline & [17] BD + STP \\
\hline & [18] Moisture + STP \\
\hline & [19] WCS + STP \\
\hline & {$[20] \mathrm{L}+\mathrm{STP}$} \\
\hline \multirow[t]{7}{*}{ Quadratic models } & {$[21] \mathrm{PR}+\mathrm{PR}^{2}+\mathrm{STP}$} \\
\hline & [22] MaxD + $\mathrm{MaxD}^{2}+\mathrm{STP}$ \\
\hline & [23] Nsam + Nsam ${ }^{2}+\mathrm{STP}$ \\
\hline & [24] Moisture + Moisture $^{2}+$ STP \\
\hline & {$[25] \mathrm{BD}+\mathrm{BD}^{2}+\mathrm{STP}$} \\
\hline & {$[26] \mathrm{WCS}+\mathrm{WCS}^{2}+\mathrm{STP}$} \\
\hline & {$[27] \mathrm{L}+\mathrm{L}^{2}+\mathrm{STP}$} \\
\hline
\end{tabular}

Abbreviations are defined in Table 2. 
Table 4 Multiplicative effect of a substantial variation in ecological variables on ecological group richness

\begin{tabular}{|c|c|c|c|c|c|c|c|c|c|c|c|}
\hline \multirow{2}{*}{ Models } & \multirow{2}{*}{ RI } & \multicolumn{3}{|c|}{ Life form } & \multicolumn{3}{|c|}{ Seed bank } & \multicolumn{2}{|c|}{ Humidity } & \multicolumn{2}{|c|}{ Light } \\
\hline & & Tree & Shrub & Herbaceous & Long-term & Short-term & Transient & Low & High & Shade & Heliophilous \\
\hline \multirow{9}{*}{$\begin{array}{l}\text { Subplot* } \\
\text { STP }\end{array}$} & $\begin{array}{l}\text { COtoBO, } \\
\text { STP30 }\end{array}$ & $\begin{array}{l}0.84 \\
{[0.54 ; 1.25]}\end{array}$ & & & & $\begin{array}{l}0.47 \\
{[0.16 ; 2.51]}\end{array}$ & & & & & \\
\hline & $\begin{array}{l}\text { COtoTR, } \\
\text { STP30 }\end{array}$ & $\begin{array}{l}1.13 \\
{[0.78 ; 1.59]}\end{array}$ & & & & $\begin{array}{l}1.20 \\
{[0.57 ; 2.83]}\end{array}$ & & & & & \\
\hline & $\begin{array}{l}\text { COtoBE, } \\
\text { STP30 }\end{array}$ & $\begin{array}{l}1.19 \\
{[0.81 ; 1.68]}\end{array}$ & & & & $\begin{array}{l}1.24 \\
{[0.54 ; 2.48]}\end{array}$ & & & & & \\
\hline & $\begin{array}{l}\text { COtoBO, } \\
\text { STP50 }\end{array}$ & $\begin{array}{l}1.01 \\
{[0.64 ; 1.49]}\end{array}$ & & & & $\begin{array}{l}0.99 \\
{[0.29 ; 3.70]}\end{array}$ & & & & & \\
\hline & $\begin{array}{l}\text { COtoTR, } \\
\text { STP50 }\end{array}$ & $\begin{array}{l}1.49^{+} \\
{[1.05 ; 2.27]}\end{array}$ & & & & $\begin{array}{l}2.69^{++} \\
{[1.13 ; 7.95]}\end{array}$ & & & & & \\
\hline & $\begin{array}{l}\text { COtoBE, } \\
\text { STP50 }\end{array}$ & $\begin{array}{l}1.68^{++} \\
{[1.20 ; 2.48]}\end{array}$ & & & & $\begin{array}{l}2.52^{+} \\
{[0.95 ; 7.04]}\end{array}$ & & & & & \\
\hline & $\begin{array}{l}\text { COtoBO, } \\
\text { STP63 }\end{array}$ & $\begin{array}{l}1.63^{++} \\
{[1.16 ; 2.52]}\end{array}$ & & & & $\begin{array}{l}3.95^{+} \\
{[0.86 ; 9.96]}\end{array}$ & & & & & \\
\hline & $\begin{array}{l}\text { COtoTR, } \\
\text { STP63 }\end{array}$ & $\begin{array}{l}2.39^{++} \\
{[1.74 ; 3.63]}\end{array}$ & & & & $\begin{array}{l}14.67^{++} \\
{[4.62 ; 30.34]}\end{array}$ & & & & & \\
\hline & $\begin{array}{l}\text { COtoBE, } \\
\text { STP63 }\end{array}$ & $\begin{array}{l}2.36^{++} \\
{[1.77 ; 3.46]}\end{array}$ & & & & $\begin{array}{l}8.91^{++} \\
{[2.92 ; 19.57]}\end{array}$ & & & & & \\
\hline \multirow[t]{2}{*}{ MaxD } & MaxD & & & & $\begin{array}{l}1.06^{0} \\
{[0.98 ; 1.15]}\end{array}$ & & & & & & \\
\hline & MaxD & & $\begin{array}{l}1.16 \\
{[1.03 ; 1.29]}\end{array}$ & & & & & & & & \\
\hline \multirow[t]{2}{*}{$\begin{array}{l}\text { MaxD + } \\
\text { STP }\end{array}$} & STP30to50 & & $\begin{array}{l}0.59^{--} \\
{[0.45 ; 0.76]}\end{array}$ & & & & & & & & \\
\hline & STP50to63 & & $\begin{array}{l}1.10 \\
{[0.86 ; 1.4]}\end{array}$ & & & & & & & & \\
\hline
\end{tabular}


Moisture Moisture

PR

$\mathrm{PR}+\mathrm{STP}$ STP30to50

STP50to63
$1.15^{+}$

$[1.09 ; 1.24]$
$1.51^{++}$

$[1.25 ; 1.80]$
$1.17^{+, 0}$

[1.11;1.23]

$1.60^{++}$

$0.96^{00}$

[0.93;1.00]

$1.44^{+}$

[1.16;1.77]

$1.11^{0}$

[1.01;1.22]

BD

$1.11^{+}$

[1.11;1.27]

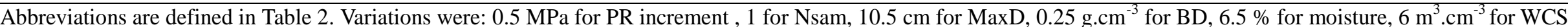
and $5 \mathrm{~m}^{2} \cdot \mathrm{ha}^{-1}$ for basal area. For stand type (STP), we calculated the associated multiplicative coefficient by supposing the stand changed from one type to the successive type: STP30 to STP50 stands $\left(\mathrm{STP}_{30 \text { to50 }}\right)$, and STP50 to STP63 stands $\left(\mathrm{STP}_{50 \mathrm{to63}}\right)$. The multiplicative coefficient for subplot location was obtained by calculating the difference between the subplot locations and the paired control (COtoBE, COtoTR and COtoBO). For quadratic models, we obtained the multiplicative coefficient for the same variation as above but calculated at first, second and third quartiles of the explanatory variable. The multiplicative coefficient for subplot location was obtained by calculating the difference between the subplot locations and the paired control (COtoBE, COtoTR and COtoBO). " 0 " and " 00 " indicate that the effect has a $p$-value of at least 0.95 of being negligible at two different levels (see text). "-" and "_" indicate that the effect has a $p$-value of at least 0.95 of being negative and non-negligible at two different levels. "+" and "++" indicate that the effect has a $p$-value of at least 0.95 of being positive and non-negligible at two different levels. Values in brackets are the $95 \%$ confidence intervals of the coefficients. 
Table 5 Multiplicative effect of a substantial variation in ecological variables on ecological group abundance

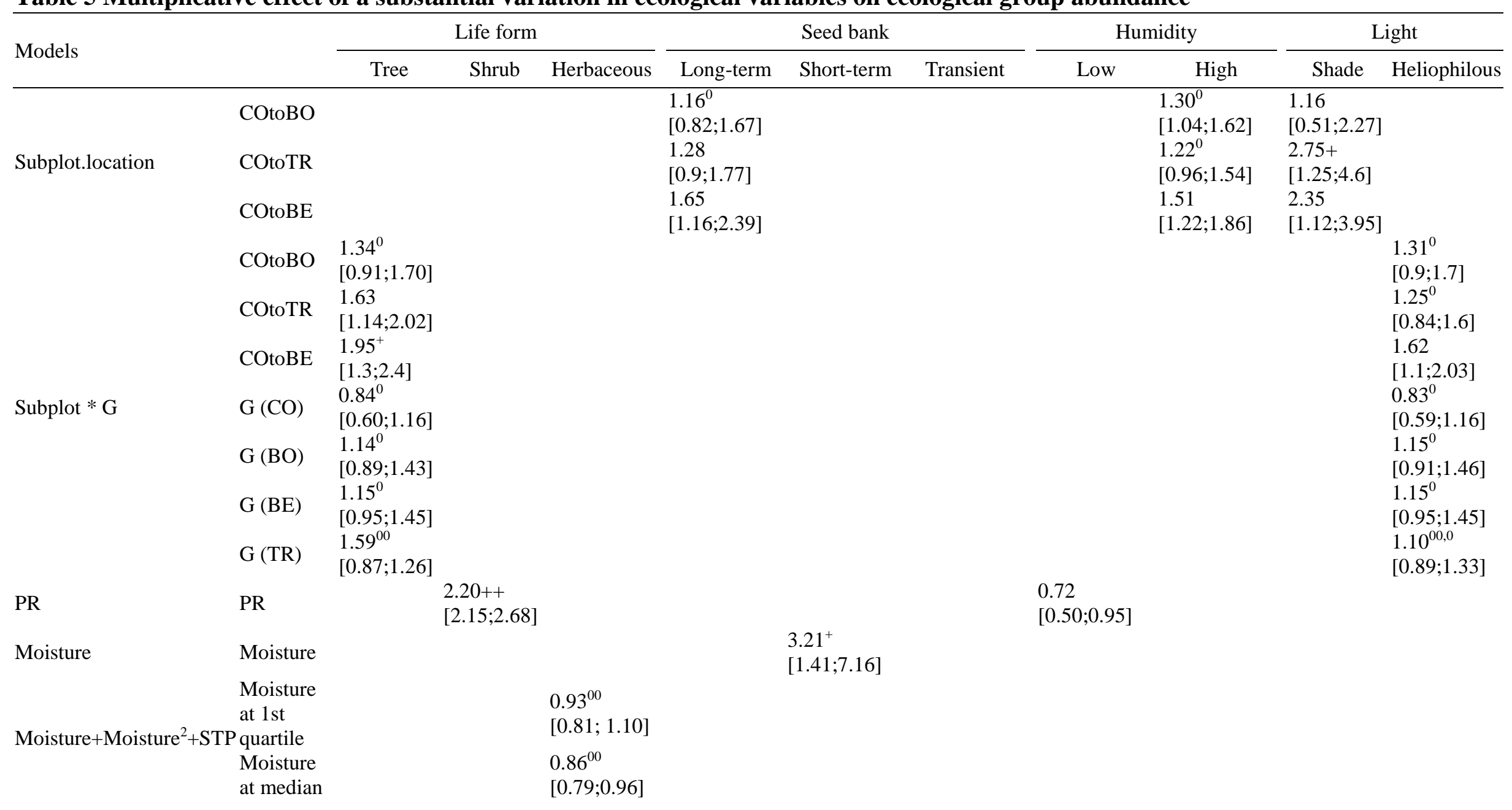




\begin{tabular}{lll} 
Moisture & $0.81^{0}$ & \\
at 3rd & {$[0.72 ; 0.88]$} & \\
quartile & $4.35^{++}$ & \\
STP30to50 & {$[2.53 ; 6.25]$} & \\
& $1.01^{\circ}$ & \\
STP50to63 & {$[0.81 ; 1.31]$} & $1.00^{00}$ \\
PR at 1st & & {$[0.92 ; 1.12]$} \\
quartile & $0.91^{0}$ \\
PR at & {$[0.84 ; 0.98]$} \\
median & & $0.83^{0}$ \\
PR at 3rd & {$[0.75 ; 0.92]$} \\
quartile & & $0.93^{00}$ \\
& STP30to50 & {$[0.78 ; 1.16]$} \\
& STP50to63 & $1.11^{0}$ \\
& & {$[0.91 ; 1.34]$} \\
\hline
\end{tabular}


Table 6 Multiplicative effect of a substantial variation in ecological variables (in the models related to light) on ecological group richness and abundance

\begin{tabular}{|c|c|c|c|c|}
\hline \multirow{2}{*}{ Models } & \multirow{2}{*}{ Variables } & \multicolumn{2}{|c|}{ Richness } & \multirow{2}{*}{$\begin{array}{l}\text { Abundance } \\
\text { Long-term seed bank }\end{array}$} \\
\hline & & Heliophilous & Herbaceous & \\
\hline $\mathrm{L}$ & $\mathrm{L}$ & $1.15[1.01 ; 1.26]$ & & $1.18^{0}[1.05 ; 1.34]$ \\
\hline \multirow{5}{*}{$\mathrm{L}+\mathrm{L}^{2}+\mathrm{STP}$} & $\mathrm{L}$ at 1 st quartile & & $0.94[0.88 ; 1.00]$ & \\
\hline & $\mathrm{L}$ at median & & $0.95[0.89 ; 1.01]$ & \\
\hline & $\mathrm{L}$ at 3 rd quartile & & $0.96^{0}[0.90 ; 1.01]$ & \\
\hline & STP30-50 & & $1.50[1.17 ; 1.97]$ & \\
\hline & STP50-63 & & $1.14^{+}[1.00 ; 1.29]$ & \\
\hline
\end{tabular}

The legend is the same as for Table 4. 
(a)

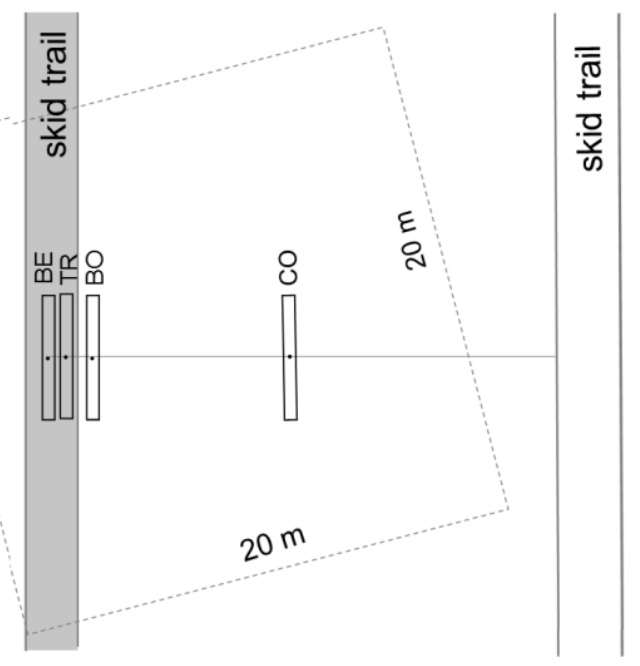

(b)

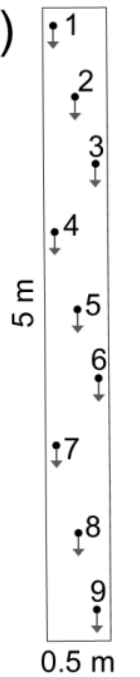

Fig. 1 (a) Subplot location (size: $0.5 \mathrm{~m} \times 5 \mathrm{~m}$ ) within the $20 \mathrm{~m} \times 20 \mathrm{~m}$ quadrats. TR: on the wheel tracks of the skid trail, BE: between the two tracks of the skid trail, BO: on the forest border next to the skid trail, CO: control, undisturbed habitat, halfway between the skid trail and the next parallel skid trail). Numbers 1-9 represent the 9 penetration resistance (PR) measurement points; arrows represent the direction of a renewed measurement when the probing rod encountered a stone or root above $20 \mathrm{~cm}$ in depth. The bulk density sample was taken at point No. 5 . 

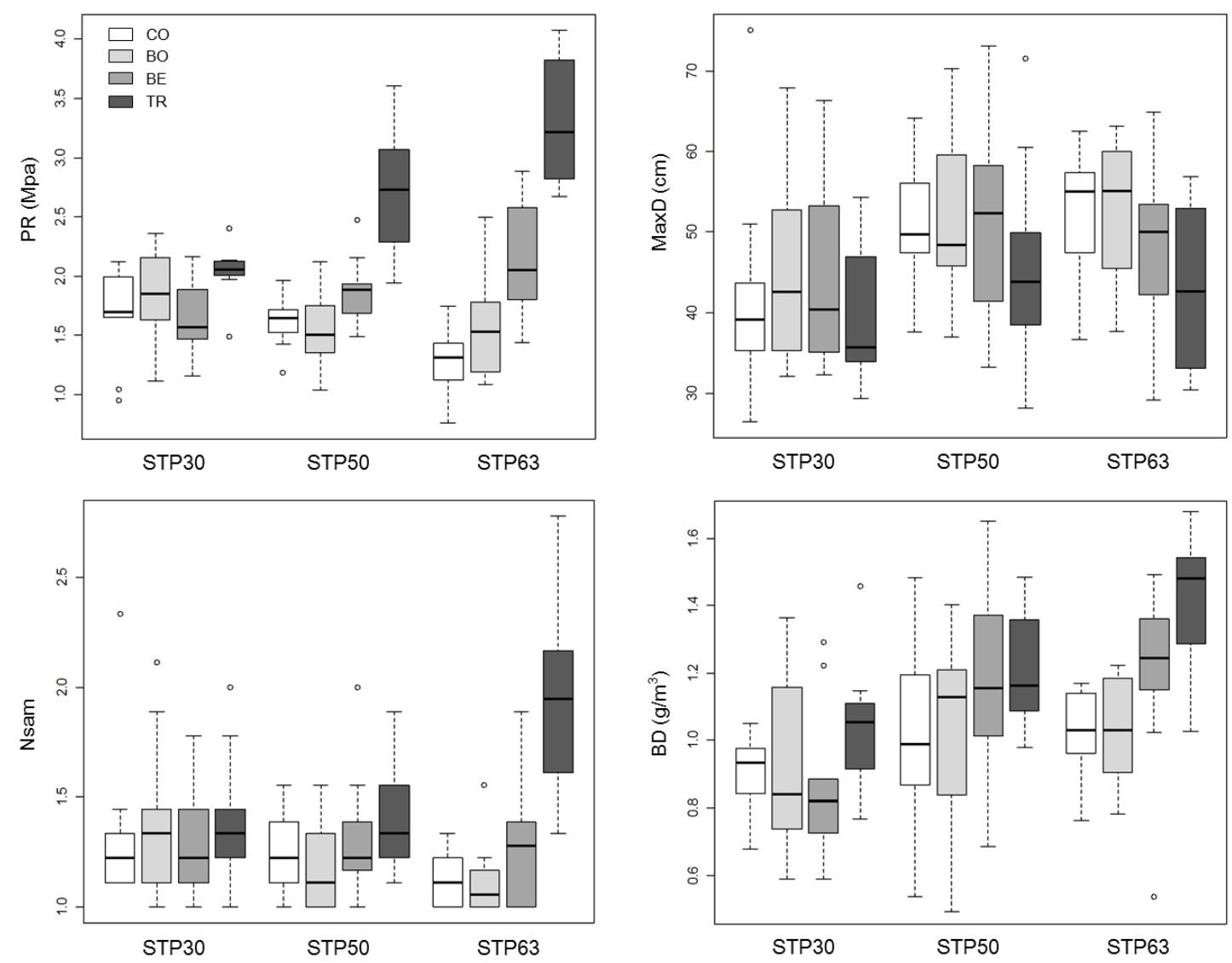

Fig. 2 Distribution of (PR), MaxD, Nsam and BD depending on subplot location (CO, BO, TR and BE) and stand type (STP30, STP50 and STP63). PR, MaxD, Nsam and $\mathrm{BD}, \mathrm{TR}, \mathrm{BE}, \mathrm{BO}$ and $\mathrm{CO}$ are defined in Table 2. 

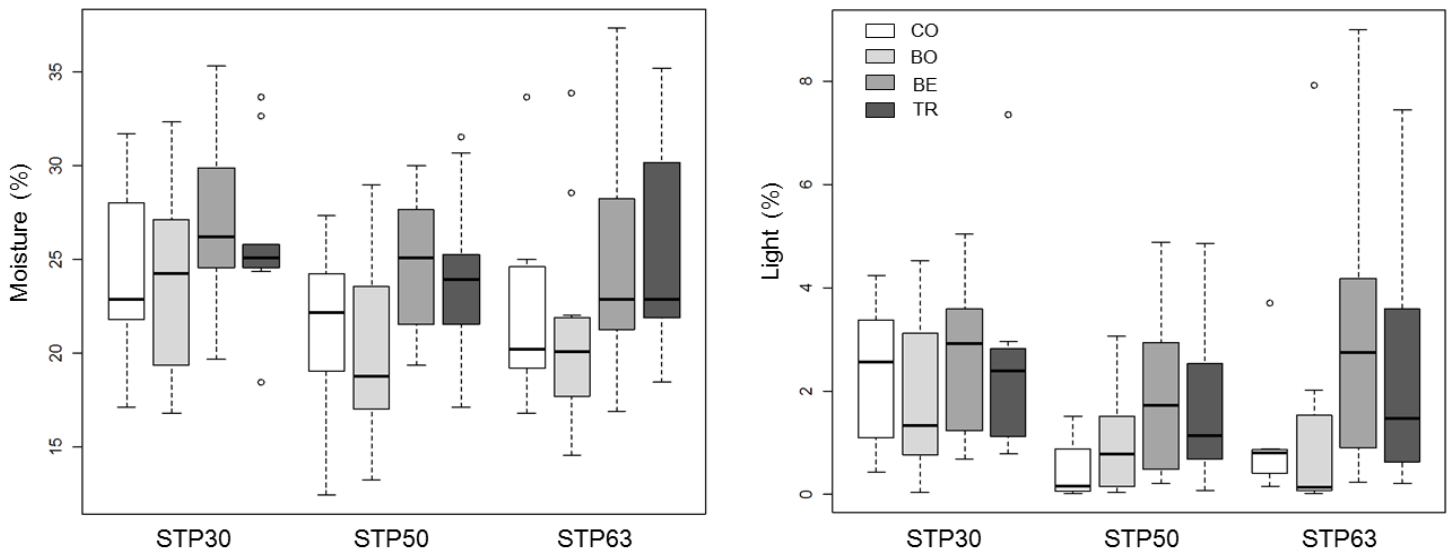

Fig. 3 The distribution of moisture and light in each subplot location $(\mathrm{CO}, \mathrm{BO}, \mathrm{TR}$ and BE) in the three stand types (STP30, STP50 and STP63). PR, MaxD, Nsam and $\mathrm{BD}, \mathrm{TR}, \mathrm{BE}, \mathrm{BO}$ and $\mathrm{CO}$ are defined in Table 2. OK 